\title{
commentary Is this old age psychiatry's rocket science? ${ }^{\dagger}$ COMMENTARY ON... CONTROLLING THE CONFUSION
}

\author{
David Jolley
}

\begin{abstract}
David Jolley has been a consultant old age psychiatrist since 1975, working first in South Manchester, then as Medical Director and Professor of Psychiatry in Wolverhampton, followed by 5 years' part-time work in Tameside and Glossop. Professor Jolley is now Honorary Reader in old age psychiatry based in the Personal Social Services Research Unit (PSSRU) at Manchester University, with clinical sessions at Gnosall Medical Centre (Staffordshire) and Willow Wood Hospice (Tameside). Correspondence Professor David Jolley, PSSRU, Manchester University, Dover Street, Mancheste M13 9PI, UK. Email: david.jolley@ manchester.ac.uk
\end{abstract}

${ }^{\dagger}$ See pp. 426-433, this issue.

\section{SUMMARY}

The Bridgend team rightly identifies the need for old age psychiatry services to work effectively with the population and staff of care homes. They describe an interesting and effective approach to this challenge, which will inform others and encourage them to make use of this system or adapt it or other ideas for use in their own locality.

\section{DECLARATION OF INTEREST}

None.
\end{abstract}

Psychogeriatics began life in the mental hospitals of the 1960s and 1970s by adapting the initiatives of community psychiatry and geriatric medicine and taking the knowledge and skills of psychiatry to older people beyond the asylum walls (Hilton 2005). The success of this movement played a significant role in the run-down and eventual closure of mental hospitals throughout England and Wales, for the last of the long-stay population was heavily skewed to old people (Jones 1993). It is ironic now to think that, although $94 \%$ of people over 65 years old live in private households, the two contexts in which older people with mental health problems are most in need of better services are institutional: in general hospitals (Mandelstam 2011) and in care homes (Which? 2011).

\section{A new world}

Colgate and colleagues address the care home challenge as exemplified within their Bridgend community (Colgate 2012, this issue). The challenge comes from the dispersal of people with the most severe and complex mental health disorders of later life between 25 sites providing 700 beds. Within those beds, patients are not directly the responsibility of the mental health teams but of primary healthcare and the regimes of a number of independent organisations who own and run care homes. Many of the latter are private companies seeking to make a profit despite mean and meagre budgets. Their funding is sometimes precarious and unstable (The Guardian 2011).
The population of 700 is not static and probably loses and gains a third to a half of its individuals every year. Some people will have been known to the responsible general practitioner for many years, others will be new to their list. Neither the general practitioner nor the mental health team is likely to have been central to agreeing placement.

The risk and often the reality is that they will be called in to solve crises when things go wrong. Hands-on staff are often paid very poorly, they may receive little training or support within their employing organisation. In many localities, staff have limited English and come from cultural backgrounds and countries where fewer people survive into late life to experience dementia in its more advanced stages.

\section{Order from chaos}

This is a nightmare situation of our own making. The Bridgend team bravely offer a systematic approach which seeks to provide education and support to staff of the care homes, and disciplined, reliable, timely responses to individual residents who may need help and support. These responses are designed to be effected before potential crises occur as far as is possible.

Their technique draws on schemas invented in hi-technology industries (rocket science or similar) that are already embraced by the more predictable medical disciplines of surgery and blood transfusion. This trick confirms Colgate's delight in the ways and languages of other disciplines: in the first article from Bridgend (Colgate 2007) we had been encouraged to speak of 'wicked' problems. I thought 'wicked' was street-talk but it has a respectable place within management-speak, if that is not a contradiction in terms. Colgate $\mathcal{E}$ Jones's 2007 article had also warmly recommended the single point of entry device provided by a lively, caring, informed clinician. This has subsequently become a mistrusted and devalued currency as the single point so often perverts to Horatio-style defending of the ramparts, repelling or delaying as many comers as possible rather than facilitating 
a friendly welcome and direction into the most relevant component of service without delay.

Within the current article the key concept is barrier analysis and the authors patiently explain the principles and how this informs what they do. Even with their help I felt my head was being squeezed painfully through a mould which did not quite fit. As Joe Egg's mum admitted as she came away from the clinic where the consultant had attempted to explain Joe's condition, she had learned quite a lot about the working of the internal combustion engine but was still not sure about Joe (Nichols 1967).

Although the team point to the power of what they deem physical or natural barriers (time-tabled visits and spreadsheets identifying vulnerable people) against chaos, neglect or error, I would say these would amount to nothing or worse unless they are used with compassion, creativity and flexibility such as are clearly present within the Bridgend team.

\section{Reflections}

There is much food for thought in these ideas. Surely every healthcare community should include a system like this to optimise the care of older people with mental health problems and a parallel service for the physically frail. I say this in the absence of formal evaluative research for it makes such obvious good sense.

That is not to speak against the idea of a funded evaluation or to suggest that the Bridgend model is the last word in how to meet this need. The likelihood is that there will be many variations on the system which will fit best within differing local schemes.
I wonder how things would look if the design started from primary care (Greaves 2011)?

I am not sure that a team not itself involved in providing residential care for very ill people is well-placed to provide education and support to others who are (Jolley 1994).

I am convinced that every system should have a safe centre, competent to provide for the most severely ill individuals within a locality, on the model of the hospice or the essence of the asylum (Hughes 2010).

\section{References}

Colgate R, Jones S (2007) Controlling the confusion: management of referrals into mental health services for older adults. Advances in Psychiatric Treatment 13: 317-24.

Colgate R, Davies K, Lambert $\mathrm{H}$, et al (2012) Controlling the confusion: using barrier analysis in the care home sector. Advances in Psychiatric Treatment 18: 426-433.

Greaves N, Greaves I (2011) The Gnosall project: setting new benchmarks for dementia care. Journal of Care Services Management 5: 1-5.

Hilton C (2005) The clinical psychiatry of late life in Britain from 1950 to 1970: an overview. International Journal of Geriatric Psychiatry 20: 423-8.

Hughes J, Lloyd-Williams M \& Sachs G (eds) (2010) Supportive Care for the Person with Dementia. Oxford University Press.

Jolley D (1994) Independent means: the benefits of closer links between the service and the private and voluntary sector. Care of the Elderly 6 : 373-4.

Jones K (1993) Asylums and After: A Revised History of the Mental Health Services from the Early 18th Century to the 1990s. Athlone Press.

Mandelstam M (2011) How We Treat The Sick. Jessica Kingsley Publishers.

Nichols P (1967) A Day in the Death of Joe Egg. Samuel French.

The Guardian (2011) Southern Cross Healthcare (http://www.guardian. co.uk/business/southerncrosshealthcare).

Which? (2011) Care homes investigation: Which? care homes investigation (http://www.which.co.uk/campaigns/food-and-health/carehomes-investigation/which-care-homes-investigation/). 